\title{
Evaluating the Ability of the Modified IIEF-5 Questionnaire to Determine the Etiopathogenesis of Erectile Dysfunction
}

\author{
Erektil Disfonksiyonu Olan Hastada Etiyolojinin Belirlenmesinde Modifiye IIEF-5 Formunun \\ Etkinliğinin Belirlenmesi
}

\section{Murat Bağcıoğlu', Ümit Yener Tekdoğan', Ali Omur Aydın², Mert Ali Karadağ', Serkan Özcan³ , Sefa Güngör', Ramazan Kocaaslan ${ }^{1}$}

${ }^{1}$ Kafkas University, Department of Urology, Kars; ${ }^{2}$ Dr. Ersin Arslan State Hospital, Department of Urology, Gaziantep; ${ }^{3}$ Artvin State Hospital, Department of Urology, Artvin; ${ }^{4}$ Çukurova Aşkm Tüfekçi State Hospital, Department of Urology, Adana, Turkey

\begin{abstract}
Aim: The aim of this study, to evaluate the ability of questions added International Index of Erectile Function-5 (IIEF-5) questionnaire differentiating the underlying etiopathogenesis of erectile dysfunction (ED).

Material and Method: The questions of the modified IIEF-5 were asked the patients, and scores below 21 were considered as ED. With added questions, smoking and drinking habits and the presence of diabetes mellitus, hypertension and coronary heart disease were recorded. The masturbation habits and night erections were also questionned. The patients were then sub-divided into 3 groups, namely psycogenic, arteriogenic and cavernosal $E D$. The results of questionnaire were correlated with penile Doppler ultrasonography $(P D U)$ results.

Results: The mean age of the 100 patients was $45.25 \pm 12.67$, and the mean duration of ED was $40.97 \pm 58.11$ months. When diagnostic ability of the modified IIEF technique was compared with PDU, the 1 st, 2nd and 3rd methods accurately diagnosed $49 \%, 75 \%$ and $79 \%$ of the patients, respectively. The kappa correlation coefficient was 18, 57 and 73 for techniques 1, 2 and 3, respectively. IIEF scores of organic and psycogenic groups were 9.92 \pm 3.94 and $12.82 \pm 4.37(p=$ 0.001). Mean IIEF scores of arterial $E D$, venous $E D$ and pyscogenic $E D$ groups were $8.6 \pm 3.34,12.32 \pm 3.86,12.32 \pm 3.86$, respectively and the arterial ED group was significantly different $(p<0.001)$.

Conclusion: Though the majority of the techniques to determine the etiopathogenesis of ED are invasive, modified IIEF is a simple and accurate technique, especially with the third step and useful for the urologists in their clinical practice.
\end{abstract}

Key words: modified IIEF-5; erectile dysfunction; etiopathogenesis

\section{ÖZET}

Amaç: Çalıșmamızın amacı, eklenen sorularla modifiye edilmiș uluslararası ereksiyon ișlevi değerlendirme formunu (IIEF-5) kullanarak erektil disfonksiyonlu (ED) hastalarda altta yatan etiyolojik faktörü öngörebilmektir.

Materyal ve Metot: Modifiye IIEF-5 formu erektil disfonksiyonu olan hastalara uygulandı ve skoru 21 'in altında olan 100 hasta ED olarak

Murat Bağcıoğlu, Kafkas Üniversitesi Tip Fakültesi Sağlık Uygulama ve Arastirma Hastanesi Üroloji Anabilim Dal, Türkiye,

Tel.05062020066Email.dr.muratbagcioglu@hotmail.com

Geliş Taribi: 11.03.2016 • Kabul Taribi: 25.03.2017 kabul edilip çalıșmaya dahil edildi. Eklenen sorularla hastaların sigara ve alkol alıșkanlıkları, diabetes mellitus, hipertansiyon ve koroner arter hastalıkları sorgulandı. mastürbasyon alıșkanlıkları ve gece ereksiyonları da ayrıca sorgulandı. Hastalar alınan cevaplara göre psikojenik, arteriyojenik ve kavernozal ED olarak 3 alt gruba ayırıldı. Formun sonuçları penil Doppler ultrason sonuçları ile karșılaștırıldı.

Bulgular: Çalıșmaya dahil edilen 100 hastanın ortalama yașı $45,25 \pm 12,67$ ve ortalama $E D$ süresi $40,97 \pm 58,11$ ay olarak hesaplandı. Modifiye IIEF-5 formunun etiyolojiyi öngören sonuçları ile penil doppler ultrasonografi sonuçları karșılaștırıldı̆̆ında 1., 2. ve 3. yöntemler için hastaların sırasıyla \%49, \%75 ve \%79'u doğru tanı aldı. kappa korelasyonu da sırasıyla 18, 57 ve 73 olarak belirlendi. Ortalama IIEF-5 skorları organik ve psikojenik gruplar için sırasıyla 9,92 $\pm 3,94$ ve $12,82 \pm 4,37$ olarak tespit edildi $(p=0,001)$. Arteriyel, venöz ve $p s i-$ kojenik gruplar için ortalama IIEF-5 değerleri ise sırasılyla $8,6 \pm 3,34$, $12,32 \pm 3,86,12,32 \pm 3,86$, iken arteriyel grubun sonuçlarının diğer gruptan istatistiksel olarak farklı olduğu gözlendi.

Sonuç: ED etiyolojisinin belirlenmesinde kullanılan yöntemlerin çoğu invaziv iken, modifiye edilmiș IIEF-5 formu ED olan hastalarda etiyolojiyi belirlemede ve tedavide ürologların klinik pratikte yararlanabileceği basit ve doğru sonuçlar veren bir testtir.

Anahtar kelimeler: modifiye IIEF-5; erektil disfonksiyon; etiyopatogenez

\section{Introduction}

Erectile dysfunction (ED) affects more than $52 \%$ of men aged $40-70$ years $^{1}$. It is estimated that over 152 million men worldwide are affected by ED; more than 322 million men will be affected in $2025^{2,3}$. Erectile dysfunction is defined as the persistent inability to achieve or maintain penile erections of sufficient value to engage in satisfactory sexual activity ${ }^{4}$. The most common underlying etiologic factors of ED are organic causes, particularly vascular insufficiency and psychological causes ${ }^{5}$. According to pathophysiology, ED is classified as organic (vasculogenic, neurogenic, hormonal, drug-induced, or anatomic/structural), psychogenic or mixed type $e^{6}$. Commonly used 
diagnostic techniques - such as penile Doppler ultrasonography (PDU), nocturnal penile monitoring, intracavernosal pharmacological tests, and cavernosometry- can yield inaccurate results, and some of these techniques are invasive. Despite its disadvantages, imaging related to ED is dominated by PDU 5 . However, patient self-reported techniques, such as the simplified version of the International Index of Erectile Function (IIEF), which consists of only 5 items (IIEF-5), has been proposed as a sexual assessment method to diagnose and classify ED in clinical trials ${ }^{7,8}$.

Here, we evaluate how well questions added to the IIEF-5 questionnaire can differentiate the underlying etiopathogenesis of ED. We correlated the results of the modified IIEF-5 questionnaire with the PDU results.

\section{Material and Method}

We included 132 patients with established ED in our study; we required that all of the patients in our cohort be followed up for a minimum of three months. The majority of patients were diagnosed between 2001 and 2011. All patients complained of the inability to achieve and/ or maintain an erection of sufficient rigidity and duration to permit satisfactory sexual performance. We obtained a detailed medical and sexual history from each patient. We then conducted a physical examination of each patient, including an assessment of genitourinary, endocrine, vascular, and neurologic systems. We also obtained laboratory tests, including fasting glucose, a lipid profile, a morning sample of total testosterone, and PSA level, in men over the age of 45 .

Exclusion criteria for this study included the presence of any neurological or hormonal (including testosterone, prolactin and thyroid hormones) disorders, a low intellect level, abnormal penile examination (Peyronie disease), a past medical history of any pelvic surgery or drug use that may cause ED and liver or kidney dysfunction. Thirty-two patients were excluded from the study based on these criteria.

The patients were informed about the aim of the study, and written informed consent was obtained from all patients. Next, we asked questions from the modified IIEF using a face-to-face technique. IIEF- 5 scores below 21 were considered to be representative of ED. The questions that we added were related to smoking and drinking habits and the presence of diabetes mellitus (DM), hypertension (HT) and coronary heart disease (CHD). The patients'masturbation habits and night erections were also questioned.
We then divided the patients into three groups based on their responses to the modified IIEF-5 questions. We conducted this division using three different techniques. In the first technique, patients with a smoking history of at least 10 pack-years or patients with a history of alcohol abuse or a past medical history of DM, HT or CHD for at least 5 years were considered to represent cases of 'organic'ED; all other patients were sub-grouped as 'psychogenic' ED. The patients with organic ED were sub-classified into 2 groups as follows: patients with a chief complaint of inability to achieve a rigid erection (question 3 on the IIEF) were considered to be cases of 'arteriogenic' ED, and patients with a chief complaint of the inability to preserve an erection (question 4 on the IIEF) were considered to be cases of 'cavernosal' ED.

In the second technique, patients who maintained successful masturbation habits and night erections were considered to be 'psychogenic'. The patients in the organic group were sub-classified into 2 groups as follows: patients with a chief complaint of the inability to achieve a rigid erection (question 3 on the IIEF) were considered to be cases of 'arteriogenic' ED, and patients with a chief complaint of the inability to preserve an erection (question 4 on the IIEF) were considered to be cases of 'cavernosal' ED.

In the third technique, we modified our methodology outlined in the previous paragraph. Patients with psychogenic ED were placed in the cavernosal ED group if their chief complaint was the inability to preserve an erection. As a summary, patients were sub-divided into three groups: namely psychogenic, arteriogenic and cavernosal ED.

Patients then underwent color-Doppler ultrasonography using a Hitachi EUB 555 high-resolution imager with a $7.5 \mathrm{MHz}$ linear probe. We monitored arterial and venous blood flow before and 15 minutes after a $60 \mathrm{mg}$ intracavernosal papaverine injection. The following combination of maximum systolic flow (MSF) above $35 \mathrm{~cm} /$ second, end-diastolic flow (EDF) less than $5 \mathrm{~cm} /$ second and resistive index (RI=MSH-DSH/ $\mathrm{MSH}$ ) above $0.9 \mathrm{~cm} /$ second was considered to be a 'normal'PDU result. Patients with a MSH below 35 $\mathrm{cm} /$ second were considered to exhibit 'arterial insufficiency' regardless of their DSH; the remaining patients with a DSH above $5 \mathrm{~cm} /$ second were considered to have 'cavernosal insufficiency'.

We then compared the groups determined using the modified IIEF technique and PDU; we employed a 
kappa test to make these comparisons. We set significance at 5\%. Taking the PDU results as a definitive diagnosis, we compared the accuracy of the modified IIEF with the PDU results. Kappa values between 21 and 40 were considered to be 'correlated', and values between 41 and 60 were considered to be 'moderately correlated.'Values between 81 and 100 were considered to be 'highly correlated'. Furthermore, we determined sensitivity and specificity of the modified IIEF for diagnosing the three sub-groups of ED patients.

We measured the percentage distribution of risk factors according to Doppler USG. We analyzed the IIEF results of patients with psychogenic and organic ED using the Kruskal-Wallis and Mann-Whitney tests.

\section{Results}

The mean age of the 100 patients included in our study was $45.25 \pm 12.67$ years (range: $22-75$ years), and the mean duration of ED was $40.97 \pm 58.11$ months (range: 3-384 months). Sixty-one patients described night erections, and 19 patients described successful masturbation. A history of DM, HT and smoking was recorded in 26, 5 and 59 patients, respectively. All of these patients except for one were older than 40 . Sixtyone patients were older than 40 , and 39 patients were younger than 40 . The mean age of patients older than 40 was $53.34 \pm 8.55$ years, and the mean age of patients younger than 40 was $32.59 \pm 5.75$ years.

The mean duration of smoking was $254.94 \pm 144.04$ months, and all patients except for one had been smoking for at least 5 years.

When we compared the diagnostic ability of the modified IIEF technique with PDU, the 1st, 2 nd and 3 rd techniques accurately diagnosed $49 \%, 75 \%$ and $79 \%$ of the patients, respectively. The kappa correlation coefficient was 18,57 and 73 for techniques 1,2 and 3 of the modified IIEF, respectively. The patient distribution with the modified IIEF technique is shown in Tables 1-3.

The mean IIEF scores of the organic and psychogenic groups were $9.92 \pm 3.94$ and $12.82 \pm 4.37$, respectively $(p$ $=0.001)$. The mean IIEF scores of the arterial, cavernosal and pyschogenic ED groups were $8.6 \pm 3.34$ (range: $4-15$ ), $12.32 \pm 3.86$ (range: 5-19) and 12.32 \pm 3.86 (range: 5-19), respectively, and the arterial ED group was significantly different $(\mathrm{p}<0.001)$. With the third division technique, which yielded the most reliable results, results that were consistent with those of PDU were obtained for 79 of the patients (79\%).

\section{Discussion}

Erectile dysfunction is a problem more frequently observed in the elderly population; symptoms typically become more serious with increasing age ${ }^{9}$. Vasculogenic and psychogenic factors are among the more common underlying etiological factors of $\mathrm{ED}^{10}$. Smoking, DM, $\mathrm{CHD}, \mathrm{HT}$ and metabolic syndrome are among the most prevalent risk factors that increase significantly the incidence of $\mathrm{ED}^{10,11}$. However, the presence of more than one of these factors in the same patient and the concomitant use of drugs that may cause ED poses a challenge for identifying novel risk factors. Similarly, the chronic diseases noted above have the potential to cause psychological problems and may cause psychogenic ED.

Although the risk factors highlighted above are known to predispose a patient to ED, not all patients with these factors develop ED. It is also difficult to determine whether there is an organic component of ED in patients with these risk factors. It is less-well known whether the duration of these risk factors or the severity of these diseases are correlated with ED.

\begin{tabular}{|c|c|c|c|c|}
\hline \multirow[b]{2}{*}{$\begin{array}{l}\text { Comparison of } \\
\text { Step } 1 \text { and PDU }\end{array}$} & \multicolumn{3}{|c|}{ Doppler } & \multirow[b]{2}{*}{ Total } \\
\hline & $\begin{array}{c}\text { Arterial } \\
\text { ED }\end{array}$ & $\begin{array}{c}\text { Psycogenic } \\
\text { ED }\end{array}$ & $\begin{array}{c}\text { Venous } \\
\text { ED }\end{array}$ & \\
\hline $\begin{array}{l}\text { Arterial } \\
\text { ED (N) }\end{array}$ & 35 & 26 & 8 & 69 \\
\hline $\begin{array}{l}\text { Psycogenic } \\
\text { ED (N) }\end{array}$ & 2 & 9 & 3 & 14 \\
\hline $\begin{array}{l}\text { Cavernosal } \\
\text { ED (N) }\end{array}$ & 3 & 3 & 11 & 17 \\
\hline Total (N) & 40 & 38 & 22 & 100 \\
\hline
\end{tabular}

\begin{tabular}{|c|c|c|c|c|}
\hline \multirow[b]{2}{*}{$\begin{array}{l}\text { Comparison } \\
\text { of Step } 1 \text { and } \\
\text { PDU }\end{array}$} & \multicolumn{3}{|c|}{ Doppler } & \multirow[b]{2}{*}{ Total } \\
\hline & $\begin{array}{c}\text { Arterial } \\
\text { ED }\end{array}$ & $\begin{array}{c}\text { Psycogenic } \\
\text { ED }\end{array}$ & $\begin{array}{c}\text { Venous } \\
\text { ED }\end{array}$ & \\
\hline & 32 & 1 & 2 & 35 \\
\hline Arterial & 6 & 37 & 19 & 62 \\
\hline$E D(N)$ & 2 & 0 & 1 & 3 \\
\hline Psycogenic & 40 & 38 & 22 & 100 \\
\hline
\end{tabular}

$\begin{aligned} & \text { Table 3. Comparison of PDU results and } \\
& \text { etiological factors as determined by technique } 3\end{aligned}$
\begin{tabular}{lcccc} 
& \multicolumn{4}{c}{ Doppler } \\
\cline { 2 - 4 } $\begin{array}{l}\text { Comparison of } \\
\text { Step 3 and PDU }\end{array}$ & $\begin{array}{c}\text { Arterial } \\
\text { ED }\end{array}$ & $\begin{array}{c}\text { Psycogenic } \\
\text { ED }\end{array}$ & $\begin{array}{c}\text { Venous } \\
\text { ED }\end{array}$ & Total \\
\hline $\begin{array}{l}\text { Arterial } \\
\text { ED (N) }\end{array}$ & 33 & 1 & 2 & 36 \\
$\begin{array}{l}\text { Psycogenic } \\
\text { ED (N) }\end{array}$ & 3 & 33 & 7 & 43 \\
$\begin{array}{l}\text { Cavernosal } \\
\text { ED (N) }\end{array}$ & 4 & 4 & 13 & 21 \\
Total (N) & 40 & 38 & 22 & 100 \\
\hline ED: Erectile Dysfunction & & &
\end{tabular}


Diagnostic techniques, such as penile Doppler USG, cavernosometry, follow-up for nocturnal penile tumescence and penile plathysmography typically necessitate specialized, expensive equipment; many of these techniques are additionally rather invasive. Therefore, the majority of these techniques are not readily available in many clinics. For all of these reasons, the etiological factors for ED can be difficult to identify.

After PDE type 5 inhibitors became more commonly and successfully used for the treatment of ED, the search for the underlying etiology of ED has become less of an issue. Even so, it is important to note that the efficacy of some PDE 5 type inhibitors varies for different etiologies of $\mathrm{ED}^{12,13}$. However, the efficacy of oral drugs to treat ED differs based on the risk factors or underlying etiologies ofED. Therefore, sufficient knowledge about the underlying etiology of ED in a patient is beneficial before starting the therapy ${ }^{14}$.

The IIEF scale is known to demonstrate the degree of $\mathrm{ED}$, but this scale is unable to determine the underlying etiology unless an invasive diagnostic modality is used as an adjunct. Our results using technique 3 of the modified IIEF exhibited similar results as those recovered with PDU in $79 \%$ of our patients. This result is consistent with the findings of Hatzichristou et al. who showed that commonly used diagnostic techniques can accurately diagnose approximately $80 \%$ of patients ${ }^{15}$. Today, PDU is also considered to be one of the most common techniques for diagnosing $\mathrm{ED}^{16}$. On the other hand, the intracavitary agents used in PDU are against the normal physiological mechanisms, by their direct smooth muscle relaxing abilities; PDU accordingly has a low accuracy rate ${ }^{17}$.

Even though Tang et al. and Deveci et al. have reported that the simplified IIEF-5 is not a definitive diagnostic tool to discriminate the pathophysiological causes of ED, our data showed that this scale can be used with a modification ${ }^{18,19}$. However, Cordeiro et al. concluded in their study that the IIEF-5 was associated with the diagnosis of coronary artery disease and that its use could add information risk stratification in hypertensive patients ${ }^{20}$. By using the modified IIEF technique, particularly after its third technique, the underlying etiology of ED can be determined in the majority of cases. This scale is accordingly an important asset to urologists.

Although the majority of the techniques to determine the pathogenesis of ED are invasive, the modified IIEF is a simple and accurate technique, particularly after its third technique. This scale is of great use to urologists in their clinical practice.

\section{References}

1. O'Donnell AB, Araujo AB, McKinlay JB. The health of normally aging men: The Massachusetts Male Aging Study(1987-2004). Exp Gerontol 2004;39:975-84.

2. Ayta IA, McKinlay JB, Krane RJ. The likely worldwide increase in erectile dysfunction between 1995 and 2025 and some possible policy consequences. BJU Int 1999;84:50-6.

3. McKinlay JB. The worldwide prevalence and epidemiology of erectile dysfunction. Int J Impot Res 2000;12(4):6-11.

4. NIH Consensus conference. Impotance. NIH Consensus development panel on Impotance. JAMA 1993;270(1):83-90.

5. Patel D V, Halls J, Patel U. Investigation of erectile dysfunction. Br J Radiol 2012;85:69-78.

6. Hatzimouratidis K, Eardley I, Giuliano F, et al. Guidelines on male sexual dysfunction: Erectile dysfunction and premature ejaculation. The Netherlands: European Association of Urology; 2015. http:// uroweb.org/guideline/male-sexual-dysfunction/

7. Rosen RC, Riley A, Wagner G et al. The international index of erectile function (IIEF): a multidimensional scale for assessment of erectile dysfunction. Urology 1997;49:822-30.

8. Rosen RC, Cappelleri JC, Smith MD et al. Development and evaluation of an abridged, 5-item version of the International Index of Erectile Function (IIEF-5)as a diagnostic tool for erectile dysfunction. Int J Impot Res 1999;11:319-26.

9. Akkus E, Kadioglu A, Esen A et al. Turkish Erectile Dysfunction Prevalance Study Group: Prevalance and correlates of erectile dysfunction in Turkey: a population-based study. Eur Urol 2002;41:298-304.

10. Shamloul R, Ghanem H. Erectile Dysfunction. Lancet 2013;381:153-65.

11. Sanjay S, Bharti GS, Manish G et al. Metabolic syndrome: an independent risk factor for erectile dysfunction. Indian J Endocrinol Metab 2015;19(2):277-82.

12. Seftel AD. Challenges in oral therapy for erectile dysfunction. J Androl 2002;23:729-36.

13. Basar M, Tekdogan UY, Yilmaz E et al. The efficacy of sildenafil in different etiologies of erectile dysfunction. Int Urol Nephrol 2001;32(3):403-07.

14. Li D, Jiang $X$, Zhang $X$ et al. Multicenter pathophysiologic investigation of erectile dysfunction in clinic outpatients in China. Urology 2012;79:601-06.

15. Hatzichristou D, Hatzimouratidis K, Bekas M et al. Diagnostic steps in the evaluation of patients with erectile dysfunction. J Urol 2002;168(2):615-20.

16. Broderick GA, Arger P. Duplex Doppler ultrasonography: non-invasive assessment of penile anatomy and function. Semin Roentgenol 1993;28(1):43-56.

17. Başar M, Başar $H$, Aydoğanli $L$ et al. Colour penile Doppler ultrasonography with intraurethral prostaglandin-E2: preliminary results. Int Urol Nephrol 1997;29(6):667-71.

18. Tang Z, Li D, Zhang $X$ et al. Comparison of the simplified International Index of Erectile Function (IIEF-5)in patients of erectile dysfunction with different pathophysiologies. BMC Urology 2014; 14:52.

19. Deveci S, O'Brien K, Ahmed A et al. Can the international index of erectile dysfunction distinguish between organic and psychogenic erectile function? BJU Int 2008;102:354-56.

20. Cordeiro AC, Mizzaci CC, Fernandes RM et al. Simplified International Index of Erectile Function (IIEF-5) and coronary artery disease in Hypertensive patients. Arq Bras Cardiol 2012;99(4):924-30. 